\title{
Morphological characteristics of Clinopodium acinos and Clinopodium suaveolens (Lamiaceae) growing in Turkey
}

\begin{abstract}
Ayla KAYA
Department of Pharmaceutical Botany, Faculty of Pharmacy, Anadolu University, 26470 Eskişehir, Turkey

Corresponding Author. E-mail: aykaya@anadolu.edu.tr (A.K.); Tel. +90-222-335 05 80; ORCID No: 0000-0002-7598-7132.

Received: 27 February 2018 / Revised: 18 May 2018 / Accepted: 22 May 2018

ABSTRACT: In this study, morphological and taxonomical characteristics of Clinopodium acinos (L.) Kuntze and C. suaveolens (Sm.) Kuntze previously treated as Acinos in Flora of Turkey were investigated. C. suaveolens grows in NorthWest and the West Anatolia and has strongly aramotic odorous while C. acinos is recorded from North Anatolia and has slight odorous. The species had been collected from different area of Turkey. They are studied for the first time using stereoscopic microscopy and detailed descriptions and illustrations of general appearance of plants and leaf, bract, flower, calyx, corolla and nutlet shapes are described and illustrated. The lengths of stem, bract, corolla and calyx lower teeth, verticil number and odorous of the plants are found significant diagnostic character to distinguish the species. At the same time, the variation borders of species in Flora of Turkey was expanded and a identification key prepared
\end{abstract}

KEYWORDS: Acinos; Clinopodium; Lamiaceae; morphology.

\section{INTRODUCTION}

Lamiaceae family is represented by 45 genera, 546 species and a total of 731 taxa in Turkey [1]. The genus Clinopodium L. is also a member of Lamiaceae family. Recently some Satureja L., Micromeria Bentham, section Pseudomelissa Bentham species and all species of Calamintha Miller and Acinos Miller have been transferred to Clinopodium by Govaerts [2], Brauchler et al. [3], Ryding [4, 5], Harley and Granda [6]. Thus, the number of species belong to genus Clinopodium has reached about to 100. They are mostly distributed in the New World and temperate Eurasia [7].

The first revision of Clinopodium was made by Davis and Leblebici [8] for the Flora of Turkey. Recently two considerable contributions on the taxonomy of Clinopodium have been made [9, 10]. After the above mentioned taxonomic studies, the number of accepted taxa in Turkey has reached to 38.

Clinopodium acinos is slightly odorous as the other is strongly odorous. C. acinos (Syn: Acinos arvensis (Lam.) Dandy) is locally known as "kayrakçayı", and C. suaveolens (Syn: Acinos suaveolens (Sm.) G. Don fil.) is locally known as "yalancı nane", "hoş feslegen" in the regions where they grow [11]. C. acinos have been used as tea and it has astrenjant effective. C. suaveolens is widely used in Balıkesir province as tea against the cold. They have also used for medicinal purposes in the literatures. For example, the decoction of C. suaveolens is used in Northern Greece as sedative, diuretic and an anti-inflammatory [12]. C. acinos, internally, is used in melancholy, for shortness of breath and for improving digestion. Externally, oil was once used to treat bruises, toothache, sciatica and neuralgia [13]. Additional, C. alpinum (L.) Kuntze is employed in folk medicine having beneficial effects an coughs and gastrointestinal disorders in Spain [14]. C. graveolens (M. Bieb.) Kuntze is used as herbal tea againts to influenza in Denizli, Kütahya, Balıkesir of Turkey [15].

Morphological and anatomical studies are played an important role in systematics. In previous publications, the compositions of essential oils of these species [16], leaf anatomical structures [17], nutlet [18] and pollen features [19] were reported by us however, morphological properties had not been studied yet. In this study, distinguishing traits of two similar species of Clinopodium have been investigated for the first time. A comparative study with different populations and herbarium materials constituted the basis of our observations. The aim of this paper is also to present morphological characters of the two species, to discuss their taxonomic values. We believed that morphological investigations on species are more useful.

How to cite this article: Kaya A. Morphological characteristics of Clinopodium acinos and Clinopodium suaveolens (Lamiaceae) growing in Turkey. J Res Pharm. 2019; 23(1): 62-68. 


\section{RESULTS}

\subsection{Clinopodium acinos (L.) Kuntze}

C. acinos is $5-41 \mathrm{~cm}$ long and perennial herbs. Stems are erect or ascending, simple or branched, with glandular and eglandular trichomes. Eglandular trichomes are crispate-pubescent or puberulent, 0.1-1.5 mm, and usually in half the upper of the stem are longer than half the lower. Leaves are green, green-purple coloured, elliptic to lanceolate, 7-18 x 3-9 mm, with petiole to 2-6 $\mathrm{mm}$, apex acute or acuminate, margin entire or serrate towards to apex, base cuneate. Veins on the lower surface of leaves are prominent, both of surface short or long, straight or patent haired. Glandular trichomes are dense and glands are big and pale yellow coloured. Floral leaves are like cauline leaves, 4-15 x 1-6.5 mm, generally exceeded to flowers, with petiole to 1-3 $\mathrm{mm}$, apex acute-acuminate, margin entire or serrate, base cuneate. The venation like leaves. Both of surfaces are long haired, margine and petiol ciliated, glandular hairs are like leaves. Bracteoles are 0.8-1 mm, subulate-lanceolate shaped, ciliated. The number of verticillasters 2-17 in the axils of the floral leaves, (2-) 6-8 flowered. The distance between verticillasters is 2-27 mm. Calyx is green, greenish-purple coloured 4-7 (-7.5) $\mathrm{mm}$, tube is straight, sub-bilabiate, prominently gibbous at the base, 13 ribbed, five toothed, lower teeth two, 1.5-2.8 $\mathrm{mm}$, subulate, ciliated, same level with upper teeth, upper teeth three, 0.8-1.8 mm, curved upwards, subulate, ciliated, generally hispidulous or pilose, glandular hairs are dense or rare. Corolla purple-lilac coloured, white in the calyx, with purple spots on the middle of lower lip, slightly exserted the calyx, (4.5-) 5$8.5(-10.5) \mathrm{mm}$, upper lip retus, 0.8-1.5 x 1.3-2.2 mm, lower lip 3 lobed, 1.2-2.5 × 2.5-4 mm, middle lobe is longer and wider than laterals, apex rotundat, from lips to tube long haired, towards to base short haired, 2 rows long-thick straight haired in lower lip, rare haired in upper lip, dense-haired in half of the tube. Stamens are 4, didynamous, filaments white coloured, $1.8-4 \mathrm{~mm}$ in lower pair, $0.8-2 \mathrm{~mm}$ in upper pair, haired or glabrous; anthers are lilac-white coloured, $0.3-1.0 \mathrm{~mm}$. Ovary is $0.5 \mathrm{~mm}$, style is white-purple coloured, 5-9.5 mm, haired or not, branches unequal, short lobe erect, subulate $0.5 \mathrm{~mm}$, long lobe larger and recurved $0.8 \mathrm{~mm}$. Nutlets are brown, reticulate, 1.3-1.8 x 0.6-0.9 mm, obovoid-oblong, trigonous, apex obtus (Figs. 1-2).

$\begin{array}{ll}\text { Flowering time } & : \text { June-July } \\ \text { Habitat } & : \text { Limestone rocks, calcareous soils, railway, pasture and fields. } \\ \text { Altitute } & : \text { to } 2000 \mathrm{~m} . \\ \text { Distribution in Turkey } & : \text { North-West, North and North-East Anatolia } \\ \text { Distribution in World } & : \text { Europe, South-West Asia, North-America, Mediterranean } \\ \text { Pyhtocography } & : \text { Euro-Sib. element } \\ \text { Climate } & : \text { Mediterranean and Continental [8] }\end{array}$

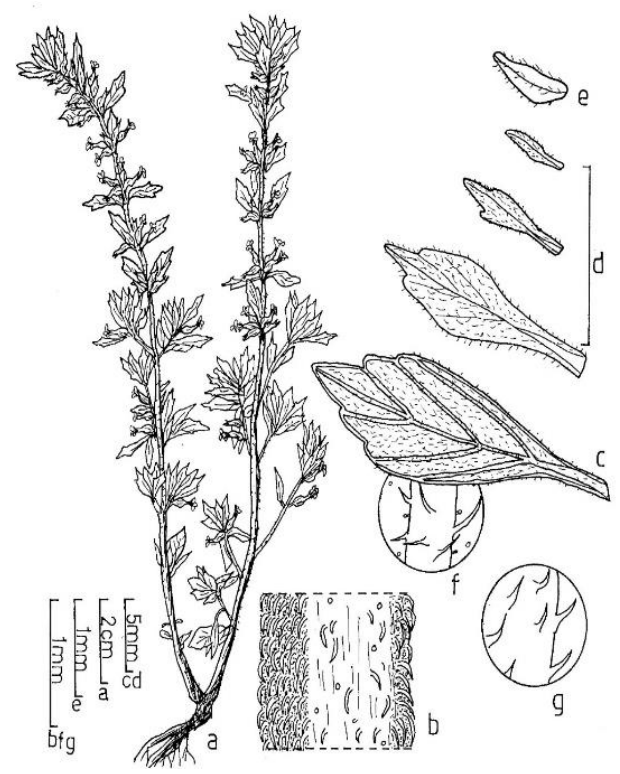

Figure 1. C. acinos, ESSE 10508, a-habit bindumentum of stem c-leaves d-bracts ebracteole $\mathrm{f}$-g-trichomes in lower and upper surface of leaves.

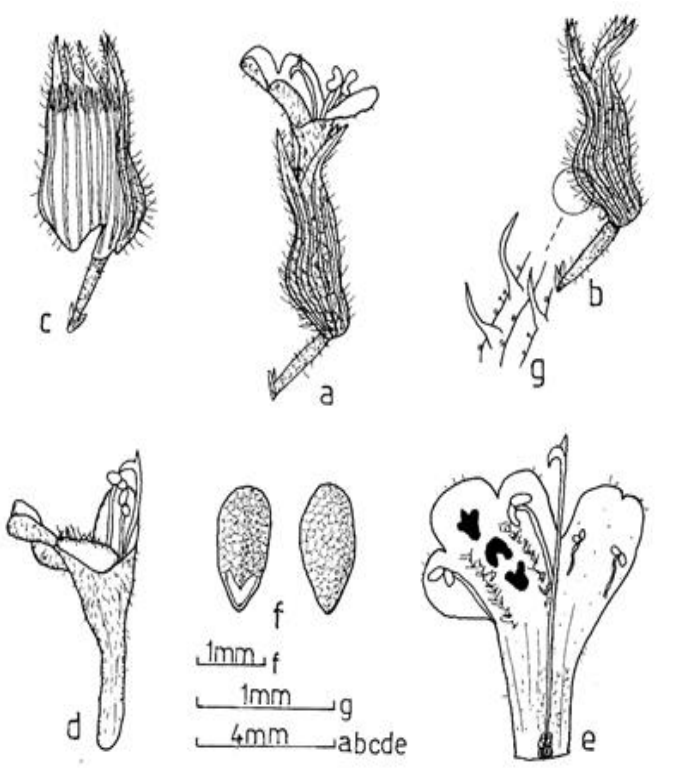

Figure 2. C. acinos, ESSE 10508, a-flower b-c-calyx d-e-corolla f-nutlets g-trichomes of calyx. 


\subsection{Clinopodium suaveolens (Sm.) Kuntze}

C. suaveolens is $8-30 \mathrm{~cm}$ long and perennial herbs. Stems are generally ascending, rarely decumbent, simple or branched, green. Glandular and eglandular trichomes on the stem are present. Eglandular trichomes are crispate or curved-haired, $0.2-1.2 \mathrm{~mm}$. Glandular trichomes are densely or sparsely. Leaves are green, ovate to elliptic-lanceolate shaped, 7-21 $\times 2.8-12 \mathrm{~mm}$, with petiole to 2-4 $\mathrm{mm}$, apex acute-acuminate, margin entire or slightly serrate, base narrow cuneate. Veins on the lower surface of leaves are prominent. Both of surface are usually long and densely or rarerly short and slightly-haired, margine and petiol are ciliate, both of surface are densely glandular hairs and glands are colourless or pale yellow-coloured. Floral leaves are ellipticlanceolate shaped, $4.5-18 \times 0.9-8 \mathrm{~mm}$, seldom exceeded to flowers, with petiole to $0.5-4 \mathrm{~mm}$, apex acuteacuminate, margin entire or weakly serrate, base narrow cuneate. The venation and trichomes like leaves. Bracteoles are subulate, subulate-lanceolate shaped, 1-2.8 mm, ciliate, glandular or not. The number of verticillasters are 2-13 in the axils of the floral leaves and verticillasters are 6-10 flowered. The distance between verticillasters is $3-30 \mathrm{~mm}$. Calyx is green, seldom green-purple coloured, $5.2-8 \mathrm{~mm}$ long, sub-bilabiate. Calyx tube is straight, prominently gibbous at the base, 13-ribbed, five toothed, lower teeth two, 2.5-3.5 mm, subulate, upper teeth three, 1-2.5 mm, subulate, all curved upwards, ciliate, dense and long straight or patent, soft or hard haired; glandular hairs densely colourless or pale coloured. Corolla purple-lilac, white coloured in the calyx and with purple spots on the middle of lower lip, lips exserted the calyx, 8-15 mm, upper lip emarginate, 1.8-3.2 $\times$ 2-3.5 mm, apex obtus, lower lip 3- lobed, 2.2-3.5 x 3.5-6 mm, middle lobe is longer and wider than laterals, apex slightly emarginate or rotundat, from lips to tube long haired, short-haired in the tube, 2 rows long-thick straight haired in lower lip, short and rare haired in upper lip and tube. Stamens are 4, didynamous, filaments white or slightly purplish, $2.5-4 \mathrm{~mm}$ in lower pair and haired, $1.5-2 \mathrm{~mm}$ in upper pair and hairless; anthers are purple-white coloured, $0.5-1.5 \mathrm{~mm}$. Ovary is $0.5 \mathrm{~mm}$, style is $7.5-15 \mathrm{~mm}$, whitepurple coloured, slightly haired, branches are unequal, short lobe erect, subulate $0.5 \mathrm{~mm}$, long lobe larger and recurved $0.8 \mathrm{~mm}$. Nutlets are brown, reticulate, 1.2-1.5 x 0.8-1 $\mathrm{mm}$, obovoid-oblong, trigonous, apex obtus (Figs. 4-5).

$\begin{array}{ll}\text { Flowering time } & : \text { June-July } \\ \text { Habitat } & : \text { Montane, on calcareous slopes, rocky. } \\ \text { Altitute } & : \text { to } 2000 \mathrm{~m} . \\ \text { Distribution in Turkey } & : \text { North-West and West Anatolia } \\ \text { Distribution in World } & : \text { North-East Mediterranean } \\ \text { Pyhtocography } & : \text { Medit. Element } \\ \text { Climate } & : \text { Mediterranean }[8]\end{array}$

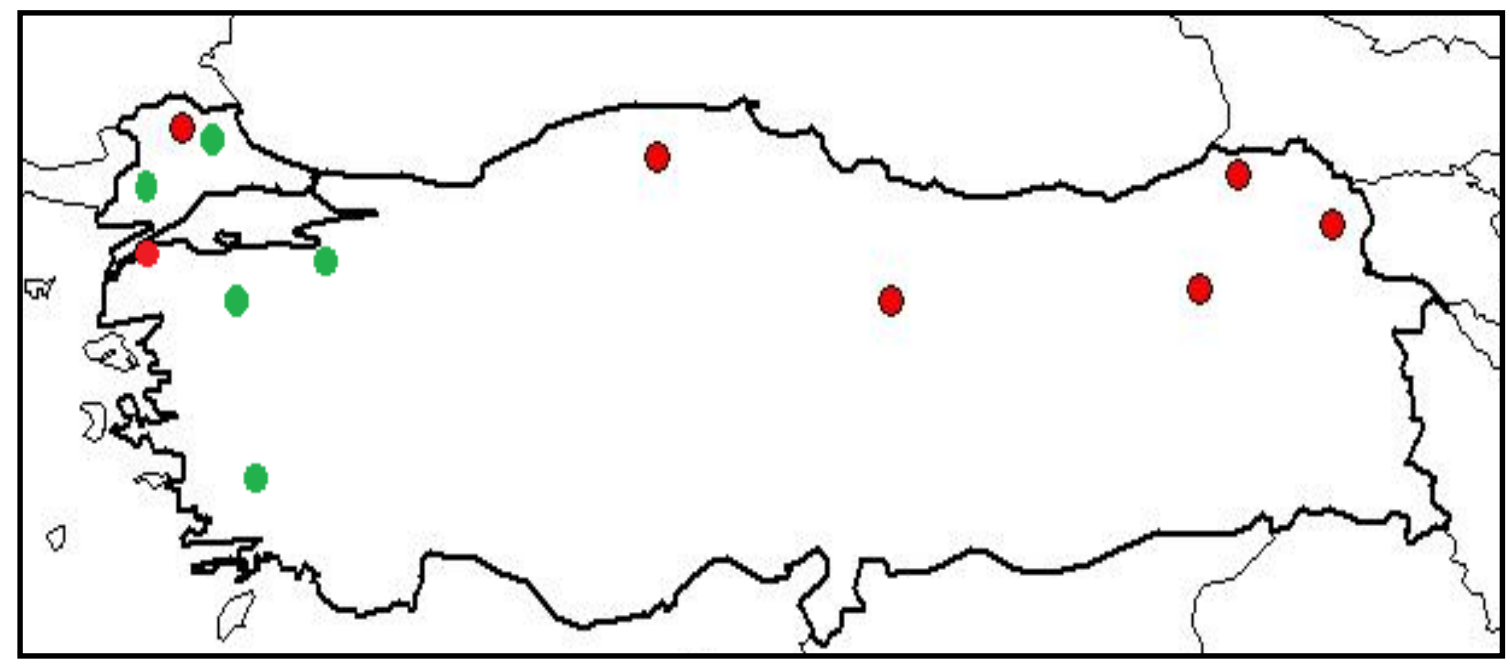

Figure 3. C. acinos (red) C. suaveolens (green). 


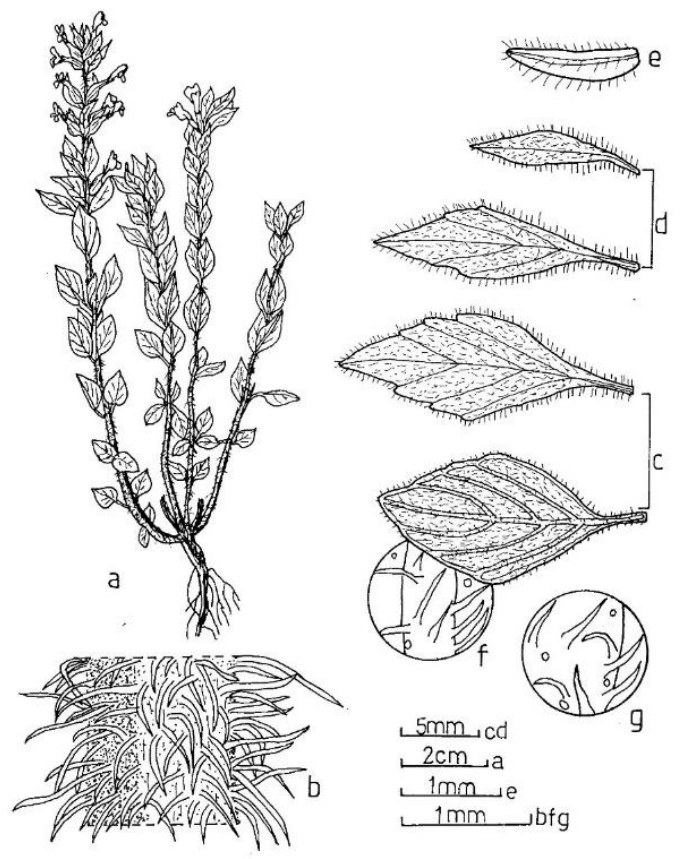

Figure 4. C. suaveolens, ESSE 10510, a-habit bindumentum of stem c-leaves d-bracts e-bracteole $\mathrm{f}$-g-trichomes in lower and upper surface of leaves.

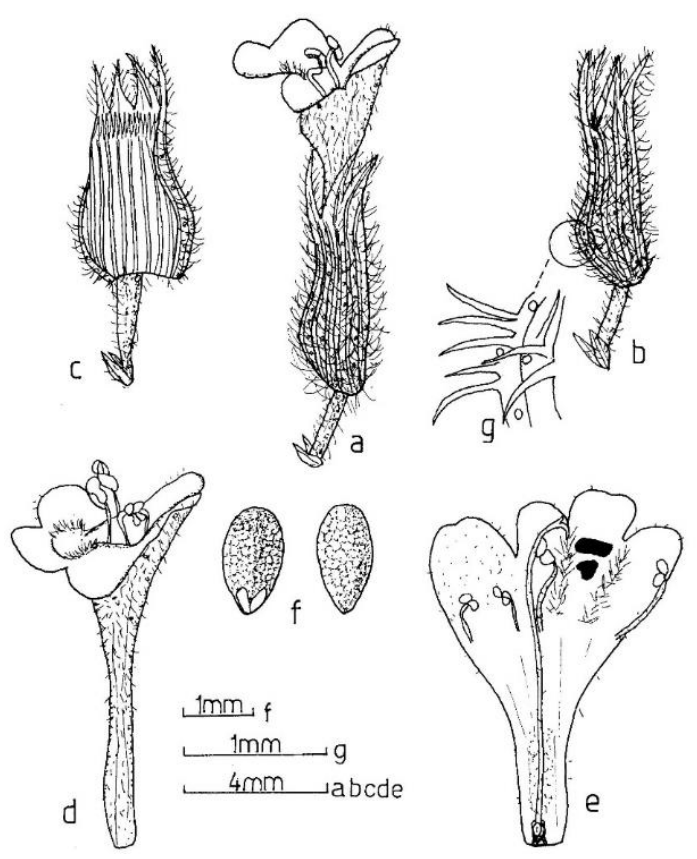

Figure 5. C. suaveolens, ESSE 10510, a-flower b-ccalyx d-e-corolla f-nutlets g-trichomes of calyx.

\section{DISCUSSION}

C. acinos and C. suaveolens samples collected very different localities (map) were investigated and compared in this study. Results of the study show that there are some morphological variations in C. acinos and C. suaveolens. However, many characters are present in all of them. According to our findings, morphological and taxonomical characteristics of $C$. acinos and $C$. suaveolens have been summarized in Table 1 and the results were compared with Flora of Turkey [8]. The lengths of stem, bract, corolla and calyx lower teeth, verticil number and odorous of the plant are significant diagnostic character to distinguish the species according to Table 1 . That is; in C. suaveolens, flowering stems are $8-30 \mathrm{~cm}$, bract $4.5-18 \times 0.9-8 \mathrm{~mm}$, calyx lower teeth 2.5-3.5 mm, corolla $8-15 \mathrm{~mm}$, verticil number 2-13 and plant is strongly odours. However, in C. acinos, flowering stems are 5-41 cm, bract 4-15 x 1-6.5 mm, calyx lower teeth 1.5-2.8 mm, corolla 5-8.5 mm and plant is slightly odours. This status is given in the separation key for the species. In addition, measurements of leaves and calyx teeth in both species and verticil number, calyx and plant lengths in only C. acinos were found higher than Flora of Turkey [8]. The others features were in accordance with the Flora of Turkey. According to result of this study, the variations borders of species were expanded. Furthermore, the stem strucure, leaf details, bract, flower number, distance between verticillasters, structure of calyx tube, properties of stamen, pistil and nutlet are reported here in detail for the first time.

We determined some variable in characters of indumentum in several populations of C. acinos. Eglandular trichomes on leaves and bracts in Kırklareli samples are long while they are small in Kastamonu and Çanakkale samples. The filament and style are glabrous in Kastamonu and Çanakkale samples but they are glabrous or haired in Kırklareli samples. In addition, glands on the calyx in Kastamonu population are denser than the other populations.

Some morphological variations were also determined in the glandular and eglandular trichomes in investigated populations of $C$. suaveolens. That is; glandular trichomes on stem and calyx in Kaz mountain and Marmara island samples are denser than Dereköy samples. Eglandular trichomes on leaves and bracts are denser and longer in Kaz mountain and Marmara island populations while they are observed both dense-long and rare-short in Dereköy population. C. suaveolens and C. acinos are also easily distinguished from their odor. Because C. suaveolens is strongly odorous while C. acinos is slightly odorous. The reason for the strong odor is pulegone (23.2-80.7\%) and isomenthone (1.1-51.1\%) [16]. 
Table 1. A comprasion of distiguishing traits of C. suaveolens and C. acinos.

\begin{tabular}{|c|c|c|c|c|}
\hline & C. suaveolens & $\begin{array}{l}\text { Flora of } \\
\text { Turkey }\end{array}$ & C. acinos & $\begin{array}{l}\text { Flora of } \\
\text { Turkey }\end{array}$ \\
\hline Plant & $8-30 \mathrm{~cm}$ & $8-30 \mathrm{~cm}$ & $5-41 \mathrm{~cm}$ & $15-30 \mathrm{~cm}$ \\
\hline Stem & $\begin{array}{l}\text { Ascending sometimes } \\
\text { decumbent }\end{array}$ & - & Erect or ascending & - \\
\hline Indumentum & $\begin{array}{l}\text { Glandular and eglandular } \\
\text { crispate or curved-haired } \\
0.2-1.2 \mathrm{~mm}\end{array}$ & $\begin{array}{l}\text { Crispate- } \\
\text { pubescent }\end{array}$ & $\begin{array}{l}\text { Glandular and eglandular } \\
\text { crispate-pubescent or } \\
\text { puberulent } 0.1-1.5 \mathrm{~mm}\end{array}$ & $\begin{array}{l}\text { Crispate- } \\
\text { pubescent, or } \\
\text { puberulent }\end{array}$ \\
\hline Leaves & Ovate, elliptic to lanceolate & & Elliptic to lanceolate & \\
\hline & $7-21 \times 2.8-12 \mathrm{~mm}$ & $8-19 \times 3-8 \mathrm{~mm}$ & $7-18 \times 3-9 \mathrm{~mm}$ & $8-15 \times 3-6 \mathrm{~mm}$ \\
\hline apex & Acute, acuminate & - & Acute, acuminate & - \\
\hline margine & Entire or weakly serrate & - & $\begin{array}{l}\text { Entire or serrate towards } \\
\text { apex }\end{array}$ & - \\
\hline base & Cuneate & - & Cuneate & - \\
\hline vein & $\begin{array}{l}\text { Slightly prominent } \\
\text { beneath }\end{array}$ & - & $\begin{array}{l}\text { Slightly prominent } \\
\text { beneath }\end{array}$ & - \\
\hline & Elliptic-lanceolate & - & Elliptic-lanceolate & - \\
\hline Bract & $\begin{array}{l}4.5-18 \times 0.9-8 \mathrm{~mm} \\
\text { seldom floral leaves } \\
\text { exceed flowers }\end{array}$ & & $\begin{array}{l}4-15 \times 1-6.5 \mathrm{~mm} \\
\text { generally floral leaves } \\
\text { exceed flowers }\end{array}$ & \\
\hline $\begin{array}{l}\text { Verticil } \\
\text { number }\end{array}$ & $2-13$ & $4-12$ & $2-17$ & $3-10$ \\
\hline flower number & 6-10 & - & $(2-)$ 6-8 & - \\
\hline $\begin{array}{l}\text { Verticil } \\
\text { distance }\end{array}$ & $0.3-3 \mathrm{~cm}$ & - & $0.2-2.7 \mathrm{~cm}$ & - \\
\hline Calyx & $5.2-8 \mathrm{~mm}$ & $6-8 \mathrm{~mm}$ & $4-7 \mathrm{~mm}$ & $4-5.5 \mathrm{~mm}$ \\
\hline $\begin{array}{l}\text { Calyx } \\
\text { tube }\end{array}$ & $\begin{array}{l}\text { Straight prominently } \\
\text { gibbous below }\end{array}$ & - & $\begin{array}{l}\text { Straight prominently } \\
\text { gibbous below }\end{array}$ & - \\
\hline C. lower teeth & $2.5-3.5 \mathrm{~mm}$ & $2.5-3 \mathrm{~mm}$ & $1.5-2.8 \mathrm{~mm}$ & $1-2 \mathrm{~mm}$ \\
\hline C. upper teeth & $1-2.5 \mathrm{~mm}$ & $1-1.5 \mathrm{~mm}$ & $0.8-1.8 \mathrm{~mm}$ & $1-2 \mathrm{~mm}$ \\
\hline Corolla colour & Purple -lilac & Violet & Purple-lilac & Violet-lilac \\
\hline $\begin{array}{l}\text { Corolla } \\
\text { dimension }\end{array}$ & 8-15 mm & 9-14 mm & (4.5-) 5-8.5 (-10.5) mm & 6-8 (-9)mm \\
\hline Nutlets & $1.2-1.5 \times 0.8-1 \mathrm{~mm}$ & unknown & $1.3-1.8 \times 0.6-0.9 \mathrm{~mm}$ & unknown \\
\hline Odorous & strong & - & slight & - \\
\hline
\end{tabular}

\section{Identification key for the species}

Lower calyx teeth $2.5-3.5 \mathrm{~mm}$, calyx 5.2-8 $\mathrm{mm}$, corolla $8-15 \mathrm{~mm}$, strongly odorous

C. suaveolens

Lower calyx teeth 1.5-2.8 mm, calyx 4-7 (7.5) $\mathrm{mm}$, corolla 5-8.5 mm, slightly odorous

C. acinos

\section{CONCLUSION}

The genus Clinopodium L. is a member of Lamiaceae family. They have also used for medicinal purposes in Anatolia. C. suaveolens and C. acinos are also easily distinguished from their odor and lengths of calyx, lower calyx teeth and corolla.

\section{MATERIALS AND METHODS}

C. suaveolens was collected from Balıkesir (Marmara island and Kaz mountain), Kırklareli, Edirne provinces while C. acinos was collected from Kastamonu, Çanakkale and Kırklareli provinces. Some of them were brought as herbarium material and they are kept in the Herbarium of the faculty of Pharmacy of Anadolu 
(ESSE). Furthermore herbarium materials were also examinated from the following herbaria: ANK, AEF, EDTU, EGE, ESSE, ISTE.

Descriptions of species are based on living material. All measurements were made directly from herbarium specimens. Measurement were made a lot sample for description of each specimen. General views, stem, calyx, corolla, nutlet, leaves, bract and bracteol of species had been drawn. Drawing of plant parts had made by illustration (drawing) tube of a wild M5 A stereomacroscope.

Moreover distibutions in Turkey of species are shown on map (Fig. 3) which is based on examinated samples and recorded in Flora of Turkey.

Acknowledgements: I would like to thank the curators of AEF, ANK, EDTU, EGE, ESSE, ISTE for granting permission to examine their specimens, and F. Koca for her helping. This work was supported by the (TUBITAK) under Grant (number: TBAK-104T293-2009).

Conflict of interest statement: The author declared no conflict of interest.

\section{REFERENCES}

[1] Satıl F, Kaya A, Dirmenci, T. The taxonomic value of leaf anatomy and trichome morphology of the genus Cyclotrichium (Lamiaceae) in Turkey. Nord J Bot 2011; 29(1): 38-48. [CrossRef]

[2] Govaerts R. World checklist seed plants 3. Continental Publishing, Deurne. 1999.

[3] Bräuchler C, Meimberg H, Heubl G. New names in old world Clinopodium: The transfer of the species of Micromeria sect. Pseudomelissa to Clinopodium. Taxon 2006; 55(4): 977-981.

[4] Ryding O. Revision of the Clinopodium abyssinicum group (Labiatae). Bot J Linn Soc 2006; 150(3): 391-408. [CrossRef]

[5] Ryding O. Revision of the Clinopodium simense group (Labiatae). Kew Bulletin 2006; 61: 419-432.

[6] Harley RM, Granda AP. List of species of Tropical American Clinopodium (Labiatae), with new combinations. Kew Bulletin 2000; 55: 917-927.

[7] Harley RM, Atkins S, Budantsev AL, Cantino PD, Conn BJ, Grayer R. et al. The Families and Genera of Vascular Plants, VII. In: JW Kadereit [ed.], Flowering Plants-Dicotyledons, Lamiales, except Acanthaceae including Avicenniaceae, Labiatae. Springer-Verlag, Berlin. 2004, pp. 167-242.

[8] Davis PH, Leblebici E. Acinos, Flora of Turkey and The East Aegean Islands, In: PH Davis [ed.], Vol. 7. University Press, Edinburgh, 1982, pp. 331-335.

[9] Frrat M, Dirmenci T. Clinopodium hakkaricum (Lamiacee), a new species from Turkey. Ann Bot Fenn 2009; 46(5): 451455 .

[10] Frrat M, Akcicek E, Kaya A. Clinopodium serpyllifolium subsp. sirnakense (Lamiaceae), a new taxon from south-eastern Anatolia, Turkey. Phytotaxa. 2015; 201(2): 131-139. [CrossRef]

[11] Guner A, Aslan S, Ekim T, Vural M, Babac MT Turkiye Bitkileri Listesi (Damarlı Bitkiler); Nezahat Gokyigit Botanik Bahçesi ve Flora Araştırmaları Dernegi Yayını: İstanbul, 2012.

[12] Kokkalou E. Composition of the volatile oil from Acinos suaveolens. Planta Med 1988; 4: 340-342.

[13] Bown D. The Herb Society of America Encyclopedia of Herbs \& Their Uses; Dorling Kindersley: New York, 1995, 228.

[14] Velasco-Negueruela A, Perez-Alonso MJ, Jimenez M, Garcia FM. The volatile constituents of Acinos alpinus (L.) Moench ssp. meridionalis (Nyman) P.W. ball growing in Spain. Flav Fragr J 1993; 8(3): 127-130. [CrossRef]

[15] Kaya A. Morphological variations in Acinos alpinus and Acinos rotundifolius (Labiatae) growing in Turkey. Flora Mediterr 2002; 12: 261-274.

[16] Kaya A, Baser KHC, Tumen G, Koca F. The essential oils of Acinos suaveolens (Sm.) G.Don fil., Acinos arvensis (Lam.) Dandy and Acinos rotundifolius Pers. growing wild in Turkey. Flav Fragr J 1999; 14(1): 60-64. [CrossRef]

[17] Kaya A, Koca F. Comparative leaf anatomical studies of Acinos species (Labiatae) from Turkey. Nord J Bot 2005; 23(5): 577-588.

[18] Kaya A, Dinc M. Nutlet morphology of six Clinopodium taxa, previously treated as Acinos, in Turkey. Bio Div Conser 2014; 7(3): 119-125. 
[19] Kaya A, Kutluk H. Pollen Morphology of Acinos Miller Species Growing in Turkey. J Integr Plant Bio 2007; 49(9): 1386-1392. [CrossRef]

\section{Appendix}

Examined specimens for C. acinos: A1(E) KIRKLARELI: Kadıkoy, 13.6.1993, M.Bulak, ESSE 10534!, Velika bridge, 12.6.1985, H.Demiriz, G.Dalg1c, EDTU 178!, same place, 12.6.1985, H.Demiriz, G.Dalg1c, ESSE 10525!, Derekoy boundary, 2 km to Derekoy, 25.5.1975, A.Baytop, ISTE 31772!, ÇANAKKALE: Gelibolu, Cevizlikoy, 27.7.1983, N.Basak, G.Olgun, EDTU 4291!, same place, 27.7.1983, N.Basak, G.Olgun, ESSE 10526!, A5 KASTAMONU: Arac-Ihsangazi, 5 km to Araç 700 m, 4.7.1993, A.Kaya, I.Kaya, ESSE 10508!, Kastamonu-Arac, around kanligol, 1150 m, 4.7.1993, A.Kaya, I.Kaya, ESSE 10537!, Arac-Ihsangazi, 5 km to Arac 700 m, open Pinus nigra woodland, 24.6.1981, E.Tuzlacı, ISTE 46817!, A9 ÇORUH: Kordevan Mountain, Kutul plateau, 2000 m, 28.6.1957, Davis, Hedge, ANK 30260!.

Examined specimens for C. suaveolens: A1(E) KIRKLARELI: Derekoy, boundary road, 28.5.1994, G.Tumen, ESSE 10530!, Sogucak, 28.5.1973, A.Baytop, E.Tuzlac1, ISTE 25166!, EDIRNE: Edirne-Lalapasa, 20 km from Edirne, 22.5.1978, N.E.Ozhatay, ISTE 39495a!, BALIKESIR: Marmara Island, 10.6.1994, G.Tumen, ESSE 10529!, Marmara Island, 16.6.1968, A.Baytop, T.Avcigil, ISTE 13709!, Marmara Island, Virankoy peak, slopes on seashore, rocky placeses $200 \mathrm{~m}$, 24.8.1979, E.Tuzlac1, ISTE 43511!, B1 BALIKESIR: Edremit, Kaz Mountain, Babadag localty, 1000 m, 17.6.1987, G.Tumen, ESSE 8462!, Kaz Mountain, Guvertepe localty, 17.6.1992, G.Tumen, ESSE 10509!, Kaz Mountain, Gurleyik localty, 22.7.1992, G.Tumen, ESSE 10510!, Kaz Mountain, Karderesi road, Dokuk localty 1400 m, 3.8.1995, A.Kaya, I.Kaya, ESSE 10549!.

This is an open access article which is publicly available on our journal's website under Institutional Repository at http://dspace.marmara.edu.tr. 